\title{
CIBERCULTURA, TIC Y REDES SOCIALES: NUEVAS FORMAS DE COMUNICACIÓN PARA LAS FAMILIAS.
}

\section{CYBERCULTURE, ICT AND SOCIAL NETWORKS: NEW FORMS OF COMMUNICATION FOR FAMILIES.}

\author{
Dra. Beatriz Manzano García \\ beatrizmg@ugr.es \\ Universidad de Granada. Facultad Ciencias de la Educación. \\ Departamento Psicología Evolutiva y de la Educación \\ Campus universitario de Cartuja s/n. 18071 Granada (España)
}

Este artículo trata de la educación y del uso que se hace en los hogares españoles de las Tecnologías de la Información y la Comunicación (TIC), como un mecanismo para la expansión de nuevas formas de comunicación e interacción social en este contexto. El objetivo de esta investigación fue detectar nuevas necesidades educativas sobre el uso responsable de Internet en las familias, debido a la evolución producida en los hogares españoles sobre los equipos tecnológicos y el uso de Internet en los últimos años.

Palabras clave: Familia, Educación, Redes Sociales, TIC, Comunicación.

This article deals with the education and the uses of these technologies in Spanish households as a mechanism for the expansion of new forms of communication and social interaction in this context. The aim of this research was detect new educative needs about the responsible use of Internet in families, proper to the evolution produced in the Spanish households about technological equipment and the use of Internet in the last years.

Keywords: Family, Education, Social Networks, ICT, Communication. 


\section{Introduction}

The use of Information and Communication Technologies (ICT) has transformed the traditional ways of communication and interaction among the members of society today. In the current age we live in, ICT has become an important component. Technologies have become one of the most effective agents of change. Manzano (2015a). «Since we have moved to the 21st century, the evolving of technologies have aided increasingly the whole approach to teaching and learning» (Gunjan, 2015, p.394).

Also, ICT has come to promote a wide and diverse communication contexts and conditions among young people, recently (Solano, González \& López, 2013).

The Europe 2020 Strategy is an initiative committed to promoting a Digital Society. According to Aranda y Sanchez (2011), activities carried out by the youngest members of society have a remarkable longterm effect on how they communicate, live, study and work. Since this generation is using ICT for sharing, creating and participating in their world anytime and anywhere, this move towards a digital society is likely to be a permanent change. In this Digital Society, families play an important role in homes, in creating for children to take advantage of the Internet and minimize its dangers (Sureda, Comas \& Morey, 2010). It is in this environment where parents must be involved in different educative tasks.

According to Monereo et al. (2005), the use of technologies has created a social and cultural phenomenon resulting in new culture where citizens may communicate, work and learn through ICT and social networks anytime-anywhere. This new culture consists of a set of platforms where individual minds are mediators of people's behaviour and where the use of artifacts promotes learning (Cole, 1998; Lalueza, Bria, Crespo, Sánchez \& Luque, 2004).

Considering that ICT play an important role providing a wide range of opportunities for Mass Media and learning, it contributes to the development of culture (Maurí \& Onrubia, 2008). The use of technology has provoked advances and changes in all areas of life, including the family environment. The inclusion of ICT in homes have created new connections and new rules in this environment. Because of this, children are able to share ICT and social networks with their parents and grandparents (Velasco, López \& Noriega, 2013). Family is the universal institution whose main objective is the children's socialization to support their incorporation to the society (Lorente, Bernete \& Becerril, 2004). But currently, technologies, especially television, are equally as important as the family as a source of socialization. Children from the last decade, who Aguaded (2011) called the e-generation, have been socialized in homes by technologies. Moreover, this is an important point that communicators, producers and educators must consider, because according to Cánovas y Sahuquillo (2010), audiovisual messages, especially television, affect children's beliefs and attitudes. A new approach to learning and a new sociocultural perspective including education through ICT and social networks has emerged. In addition, according to Wertsch (1993), the environment liked any action. These arguments are support by the Vygotski's Sociocultural Theory (1980), which says that children develop their higher mental functions interacting with social and cultural environment by internalization processes. Thus, in today's society learning is the result 
of an individual interaction not only with other people, but also with technologies and social networks.

\section{Culture, cyberculture, learning and ICT from the sociocultural perspective.}

According to Hine (2004), the Internet produces its own culture called Cyberculture. Lévy (2007), created this concept and defined it as a set of cultural systems arising in conjunction with digital technologies. According to Barragán (2011), this concept has generated many reactions. On the one hand, some defend this concept as a simple way to rename a stage of development of modernity. On the other hand, others believe it is a key to understanding new interpretations of a new reality mediated by ICT. Lévy (2007) adds that cyber culture has invented another way to get the virtual presence to the Society. According to these words, Education has been reinvented and it is reconfiguring its theoretical approaches. Therefore, it has created new thoughts in the Digital Society. In this society, technological changes must go with the new educative initiatives into an educational environment (Martínez \& Raya, 2012). Moreover, «we are living in a world that has become increasingly challenging hence our approach to learning; especially in schools need to be commensurate to the social, economic and political dynamics witnessed in our global community» (Gunjan, 2015, p.394).

The introduction of ICT in all areas of life has caused a series of cultural changes. The use of ICT, Internet and social networks provoked these changes. The purpose is to get the adaption to the demands of the Digital Society. This situation has promoted a new culture of learning. In addition, it has created new training needs about the responsible use if technologies.

The Information and Knowledge Society contextualize the new culture of learning. According to these ideas, ICT are cultural artifacts that offer new possibilities for communication. According to the Vygotski's sociocultural perspective (1979) learning is a process in which to learn is as result of the relationships between the people involved through social interaction. From this perspective ICT are tools generated «for» and «by» culture.

Firstly, learners construct new learning interacting with other people when using ICT and Social Networks. At the same time, educators and learners create meaningful learning when they make tasks using ICT and Social Networks. In turn, contents facilitate relationships between both. The use of ICT and social networks has created new ways of communication and education. In addition, it has caused many cultural changes that involve not only new ways of organizing and distributing knowledge, but also the adaptation to new cultural needs. Then, in this culture of learning ICT are cultural artifacts whose use, according to Pozo y Monereo (1999), requires dominating the appropriate skills to be effective digital learning, e.g., the ability to select, organize or understand the information. Also Monereo et al. (2005) Therefore, ICT is a cultural and socio-cultural phenomenon.

\section{1. ICT and Internet as a cultural and social phenomenon.}

In today's society ICT are essential elements in the process of the creation of a new identity in young people. According to García, J.A., Navarro \& Arias (2014), ICT 
establish the cultural background of their actions and decisions. Moreover, on last decade it has increased technologies in homes. This phenomenon coincides with a structural change where cycles of networked individualism built social relations (Morimoto \& Friendland, 2011).

Over recent years, studies related to ICT have focused on analyzing the technological revolution and its impact. Nevertheless, they forgot how technologies are used and how incorporated into their lives (Hine, 2004). Other authors such as Doménech, Tirado y Vayreda (2005) have discussed the use of Internet for two sociocultural approaches:

Firstly, Internet is an element based on a model called «reduced social signal», based on the analysis of decisions making in virtual environments. According to this model, communication through ICT reduces the characteristics of learning in a communicative context. Secondly, Internet is an element that has its own characteristics. According to this argument, Internet is another means of interaction. Therefore, ICT and Internet not reduce or limit reality, but they have own characteristics. As a result, it is necessary new theoretical models. In this paper we are agree with this second approach.

Consequently, according this argument and from the studies of Hine (2004), an analysis of ICT is madden from two complementary perspectives: On the one hand, digital reality created in networks, and not by networks. In Internet, emerge symbolic connections that go further the physical connections. Therefore, it considered that ICT not only are cultural elements that promote culture and facilitate new ways of communication, but also offer adequate spaces for the social interactions. It contributes to the establishment of a new image of ICT as culture. However, to understand ICT as a cultural phenomenon, it is necessary to understand, previously, how technologies produce communication and interaction (Hine, 2004). Studies interested in the analysis of technologies, define Internet as an open space, i.e. as a cultural environment.

On the other hand, ICT are cultural artifacts or tools produced by and for the culture. Doménech et al. (2005) have defined ICT as technology generated by individuals, to get objectives, who have adapted them to its needs and characteristics. Then, culture has elaborated ICT to transmit them.

\section{ICT, families and social networks: new possibilities of communication and learning.}

Traditionally, families have played a fundamental role in the socialization of children. Actually, they try to educate them in responsible uses of technologies at home. This situation may transform the family environment in a potential environment for educating children in ICT (Cobo \& Moravec, 2011). The use of ICT is creating new ways for communicating, learning, working and studying in this environment.

During the last decade, the use of Internet has allowed us to access of a large amount of information through different types of searches as Google, Yahoo, or Alaup. At the same time, we have adopted a new concept of learning, called «mobile learning» that is supported by portable technologies (Pérez, 2011). Then, it is possible due to ICT may integrate it in different areas of life easily, such through technologies than software or social networks. Caldevilla (2010) has considered that ICT were tools able to socialize children. ICT have acquired pedagogical values for 
social meeting, chatting, discussing, writing, learning or watching videos or flash. For example, technologies as Tablet and laptops allow us connecting to Internet, playing video games, doing a course, elaborating conceptual maps, searching information, storing and sharing documents, teaching, learning or chatting. Therefore, we have discovered new forms of communication through digital tools, especially the young people called «interactive generation» and «multi-area generation», by Aguaded (2011). They are children and teenagers who were born and grown with screens. In addition, they are able to make different and simultaneous tasks at the same time. Therefore, changes produced by the digital society are contributing to create a new culture where people communicate and use ICT in many different ways. In this culture, students have grown using digital tools due to they have incorporated ICT to their daily tasks (Expósito \& Manzano, 2013). Then, it has created a generational gap based in how educators and learners use ICT. This gap impact on the social interactions as different forms of communication (Martínez \& Raya, 2010).

Social networks have provoked a revolution on the last decade facilitating the communication and interaction between people situated in different parts of the World. According to Boyd (2007) they allow us to make a public or semi-public profile within a limited system and managing a list of other users with whom sharing connection, documents, videos, pictures or messages. Moreover, they are contributing at the development of social relationships. Therefore, not only they have been an important elements gathering people for playing, discussing, sharing information and chatting, but also they have result attractive for youngest and new forms of expression and creativity through sociocultural activities (Velasco, López \& Noriega, 2013). Social networks have become as the best way of communication, interaction and global participation (García Ma . C., Del Hoyo \& Fernández, 2014). Actually, there are more than 200 types, but some of the most popular are: «Facebook, Tuenti, Twitter, Myspace, Flickr, Hi5, Youtube, LinkedIn, Line, Whatsapp, Yahoo or Google+».

The common purpose of these is to create a culture of network (Flores, 2009). Moreover, this author adds that Internet allows knowing and sharing the experiences and creations designed by other people. He called this phenomenon Science of Networks or Network Culture. However, in this new culture the most important thing is that young people learn the correct use of the technologies. Therefore, we think that the quality is more relevant that de quantity. As Cabero (2009) argument that we must ask about what is the truly impact of ICT for young people when they communicate with others by Internet. In addition, how they process the digital information. Alternatively, even, why young people changes their concept of time when they use ICT and Internet for chatting or gaming.

\section{Methodology approach.}

\subsection{Objectives.}

The main goal of this research was detect new educative needs about the responsible use of Internet in families, due to the evolution produced in the Spanish homes about technological equipment and the use of Internet in the last years. Then, in order to 
obtain this aim, it proposes to analyze the data offered by (INE) the National Statistical Institute of Spain.

\subsection{Sample, method and procedure.}

The sample is comprised of the data obtained by the National Institute of Statistics in 2007 and 2015. The data shows changes in family's habits with regard to technological equipment and the use of Internet. This is a non-probabilistic sampling, in, which intentionally selected the statistic data by analysis content and discuss. Therefore, in this paper it has analyzed data about these three different topics. Firstly, «the equipment of Spanish homes». Secondly, «the use of Internet in young people and adults» and finally, "places where the youngest use Internet». We considered that these topics were relevant for getting the objective for this research. Finally, it has compiled the data (percentages) of these topics in two different period of aged, and showing in three figures. Then, it has compared and analyzed all this data for the discussion.

\subsection{Discuss.}

According to the results obtained by the INE (2015), 99.7\% of homes consisting of four members are equipped with one or more TV; $91.3 \%$ of them have Internet access. In addition, 77.8\% have an ADSL connection; $92.5 \%$ of homes have mobile devices (computers, tablets or netbooks); $99.5 \%$ are equipped with mobile phones; and $79.8 \%$ of homes have DVD devices.

In comparison, according to the INE (2007), 99.8\% of homes consisting of four members were equipped with one or more TV; $61.1 \%$ had Internet access, in $54.4 \%$ of cases with
ADSL connection. In addition, 21.6\% of households were equipped with laptops; 4\% had other mobile devices such as PDA or PC Pocket. In total, $98.5 \%$ of families used mobile phones and $90.2 \%$ of homes were equipped with DVD players. As shown in Figure 1. According these data, there has been an evolution over the past seven years in relation to ICT equipment in Spanish homes and specifically in Internet connection, ADSL and laptops. The difference in mobile phones and televisions are less notable, which may mean that these devices were among the first technological acquisitions by Spanish families.

On the other hand (in 2015), 92\% of children between 10 and 15 years and $98.5 \%$ of young people aged between 16 and 24 years regularly make use of the Internet; $95.4 \%$ of young people aged between 25 and 34 years; $92.3 \%$ of adults aged $35-44$ years; $50.8 \%$ of adults aged between 45 and 54 years. Finally, $58.4 \%$ of adults aged 55-64 years. While in 2007, 76.9\% of children aged between 10 and 15 years made regular use of the Internet and $90.7 \%$ of young people aged between 16 and 24 years; $78.9 \%$ of young people aged between 25 and 34 years; $62.5 \%$ of adults aged between 35 and 44 years; $50.8 \%$ of adults aged between 45 and 54 years. Finally, 24.6\% of adults aged between 55 and 64 years.

Other studies as Badia, Clariana, Gotzens, Cladellas y Dezcallar (2015) youngest spend more time watching TV than playing videogames. Some authors argument that while children spend between 150 and 180 minutes per day on watching TV, adults spend 2 hours per day more than children do. (Bringué \& Sánchez, 2007). The study of Badia et al. (2015) concluded that the first children had lower performance in the math's area than the second group. This results could be 


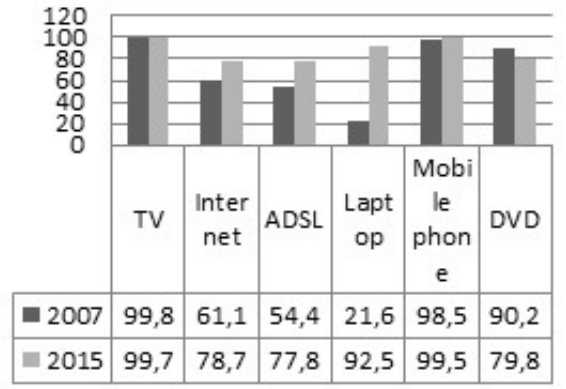

Figure 1. Statistical data relating to the equipment of Spanish homes.

according to data obtained for Rodríguez (2002) who concluded that videogames promotes logic, spontaneity and creativity in children. According to this author, videogames help children to develop their hand-eye coordination. Alternatively, Manzano (2015b) whose study about the use of videogames in schools of UK concludes that videogames help students to keep their attention on the task. However, most of studies about the effects of TV, ICT or Internet in the youngest conclude show negative effects in the children's health (obesity, inactivity, misbehavior, attentional or sleep disorders or even misbehavior), other authors as (Green \& Bavelier, 2003; Trick, Jaspers \& Sethi, 2005), show positive effects through the use of videogames by children. So, they argument that these tools stimulate certain learning areas. Likewise, other authors as Haan (2011) have reported that online educational games promote the development of ICT skills and competences among young people. However, Chik (2011) pointed out that the recognition of online games as educational tools depends on whether students consider them educational tools, or otherwise they consider that online educational games are just recreational tools.

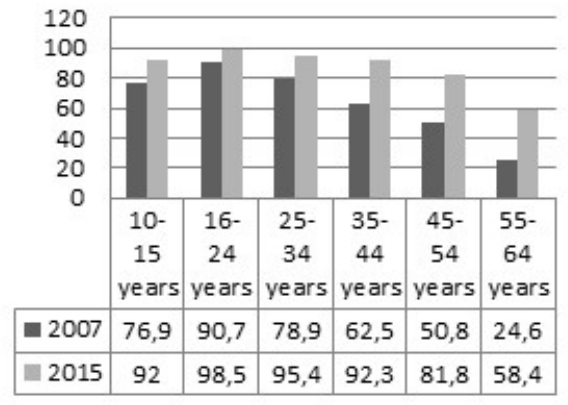

Figure 2. The use of Internet in young people and adults.

According to the Figure 2, young people between 16 and 24 years make greater use of the Internet, followed by young people between 25 and 34 years and 35 to 44 years. Then, in 2007 and in 2015 it can observe an evolution about the use of Internet.

The adults aged between 55 and 64 using Internet less than the youngest. However, there has been an increase in Internet usage by all of them in the last years. Youngest shows more intense relationship with technologies and social phenomena. So, four out ten Internet users are of less than 35 aged (ONTSI, 2014).

According to Marcelino (2015), young people between 22 and 28 aged have the strongest participation in media communication.

As for the preferred places to use ICT, in 2007, 85.4\% of children aged between 10 and 15 years were using the Internet in the family home; $31.5 \%$ accessed it with relatives and friends; $66.9 \%$ from a school or academic centre and $11.5 \%$ from cafés. However, in 2015, $89.8 \%$ of children accessed the Internet from their homes; $38.9 \%$ from the homes of family and friends; $68.9 \%$ from school and $5.2 \%$ from a cafés. 


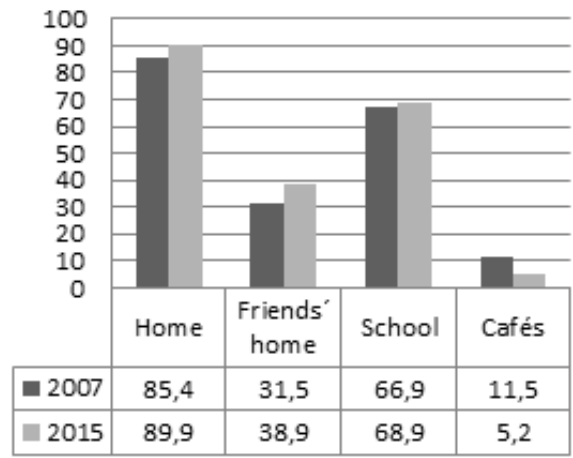

Figure 3. Places where the youngest use Internet.

As this table shows us, the first place chosen by the children to use ICT is the family home; the second is the school, followed by a friend's home and finally, cafés. According to INE (2007), children used Internet in cafés more often than in 2015. This may be due to the developments in Spanish homes in relation to ICT equipment as shown in figure 1. There was an increased from $61.1 \%$ of homes with Internet access in 2007 to $91.3 \%$ in 2015.

According to Sureda et al. (2010) 29.3\% of children aged between 6 and 14 years and $46.8 \%$ of children aged between 15 and 16 years, prefer used Internet from their own bedroom. In the last seven years has the number of homes connected to the Internet has increased, which in turn has increased the possibility for children to access at Internet from their homes. Also, according to these ideas, Sampedro y Marín (2015), youngest who used a public connection and connect more frequently (i.e., every day per week and more of four hours per day) have a better understanding of the digital tools. Therefore, they have higher level of digital skills using social and educational networks and blogs.

\section{Result and conclusions.}

According to the INE $(2007,2015)$ in the last years, the number of ADSL Internet connections in homes has increased as well as the use of laptops in families (See Figure 1). Furthermore, young people aged between 16 and 24 years are making greater use of Internet, leading to an increase in recent years in the number of people who access the Internet at all ages (See Figure 2). Other studies as (The Cocktail Analysis, 2011) concluded that in Spain, 85\% of people used a social network. In addition, digital native use social networks more frequently than people do over 45 aged.

On the other hand, a large number of Spanish families (82.3\% of cases) implemented measures restricting access to Internet. However, subsequently, according to data collected by INTECO (2013), only $17.7 \%$ of Spanish families adopted educational measures to promote the safe and responsible use of ICT with children.

Internet is the most popular place for the communication and social interaction that transcends all social barriers. ICT can play an important role in human development. Venues such as libraries and cybercafés, which offer public access to Internet can help offer more access and use of ICT for development among underserved populations in developing countries (Gomez \& Camacho, 2013). According to Pérez (2011), the possibilities of ICT are causing a great cultural transformation in society because they allow us to chat with people situated in other places, cities or even countries. (anywhere/anytime). Moreover, learning to discriminate and distinguish the correct information online is quite important for the youngest in the current society. Moreover, 
being agree with Piscitelli (2006), for the new generations, Internet is a part of their ordinary lives. In this digital environment, family relationships are being enriched by the use of ICT and Internet, especially when relatives live far away, due to sharing messages, videos or photos through different digital tools. In this case, these relationships may become as unstable as the technologies that we are used. However, an irresponsible use of the digital technologies may produce negative effects in people and families because these uses can increase of leisure time, or decrease the time to work; i.e. an irresponsible use of ICT may also involve a restructuring of daily tasks in families. The Internet is one of the most important forms of interaction in current society. Furthermore, it is the place where most of our relationships occur, at different levels and at any time (Ruiz \& De Juanas, 2013). Then the key is to educate people and not to prohibit the use of ICT.

In today's society, one of the most important changes that it has been occurred it was the adaptation to the new digital culture or cyber culture. Where ICT have become as tools use for facilitating the social relationships, communications and education anytime and anywhere. This situation, according to Monereo et al. (2005), not only has redefined relationships between machines and people, but also it has reconfigured rules of privacy, copyright or ethics.

Finally, learning and social networks are perfectly compatible. Therefore, from social responsibility perspective, it is required changes on methodologies for ensuring a use of ICT as educational and interactive tools (Martínez \& Raya, 2012). In in relation to these results, Manzano (2012) identified a lack of ICT competences among Spanish and Slovak families of primary students. In this research, it has classified the families into ICT training macro needs and micro needs. Finally, these needs were technological and educational/ pedagogical aspects of technologies, and teaching students how to make a safe and appropriate use of ICT. The development and implementation of training actions targeted at the families of elementary students contributes to meet their ICT training needs. According to these conclusions (López, Llorent \& Fernández, 2013; Sevillano, 2010) argument that the development of digital skills allows higher performance and higher quality in the educational environment. Therefore, in this paper it considered that although they are important elements of life, its application is still limited, especially for learning.

\section{References.}

Aguaded, J. I. (2011). Children and Young people: the new interactive generations. Comunicar, 18(36), 7-8. doi: 10.3916/C362011-01-01.

Aranda, D. \& Sánchez, J. (2011). Desmontando tópicos: jóvenes, redes sociales y videojuegos. En E. Martínez y C. Marta (Coords.), Jóvenes interactivos. Nuevos modos de comunicarse. (pp.119-135). La Coruña: Netbiblo.

Badia, M.M., Clariana, M., Gotzens, C., Cladellas, R. \& Dezcallar, T. (2015). Videogames, television and academic performance in elementary schools students. Pixelbit, (46), doi: http://dx.doi.org/10.12795/ pixelbit.2015.i46.02

Barragán, D.F. (2011). Teaching, Cyberculture and Cyberspace: The Change of Domain to Master Craftsman. Actualidades Pedagógicas, (58), 81-95. 
Boyd, D. (2007). Why youth (heart) social Network sites: the role of networked publics in teenage social life. Cambrigde: Press.

Bringué, X. \& Sánchez, C. (2007). Los niños y sus pantallas. ¿Quién será capaz de mediar? $X X$ Congreso Internacional de Comunicación de la Universidad de Navarra. Navarra, abril 2007.

Cabero, J. (2009). Educación 2.0. ¿Marca, moda o nueva visión de la educación?. En C. Castaño (Coord), Web 2.0. El uso de la Web en la sociedad del conocimiento. Investigación e implicaciones educativas. (pp.13-34). Venezuela: Universidad Metropolitana. Recuperado de: http:// tecnologiaedu.us.es/tecnoedu/images/ stories/castanio20.pdf

Caldevilla, D. (2010). The social webs. Typology, use and consumption of the webs 2.0 in today's digital society. Documentación de las Ciencias de la Información, 33, 45-68. Retrieved from: http://revistas.ucm.es/ index . p h p / D C I N / a r t i c le / vi ew / DCIN1010110045A/18656

Cánovas, P. \& Sahuquillo, P.M. (2010). Family education and television mediation. Teoría de la Educación: Revista Interuniversitaria, 22(1), 117-140. Retrieved from http://revistas.usal.es/index.php/11303743/index

Chik, A. (2011). Learner autonomy development through digital gameplay. Digital Culture \& Education, 3(1), 30-45.

Cobo, C. \& Moravec, J. (2011). Aprendizaje invisible. Barcelona: Universidad de Barcelona.

Cole, M. (1998). Cultural Psychology: A Once and Future Discipline. Harvard University: Press.

Doménech, M., Tirado, F.J. \& Vayreda, A. (2005). Aprender a participar en la vida pública a través de Internet. En C. Monereo
(Coord.) (2005). Internet y competencia básicas. (pp. 117-140). Barcelona: Graó.

Expósito, J. \& Manzano, B. (2013). ICT School 2.0: Elementary student learning in educational social and family contexts. EDUTEC, 45. Retrieved from: http:// edutec.rediris.es/Revelec2/Revelec45/ e s c u e l a T $_{\text {T C }}$ a p r e n dizaje_contexto_educativo_sociofamiliar.html

Flores, J. (2009). New models of communication, Profiles and Trends in Social Networks. Comunicar, 17(33), 73-81. doi: 10.3916/c33-2009-02-007

García, J.A., Navarro, F. \& Arias, F. (2014). La credibilidad de los contenidos informativos en Internet para los nativos digitales: Estudio de caso. Palabra Clave, 17(3), 875-894. doi: DOI: 10.5294/ pacla.2014.17.3.13

García, Mª C., Del Hoyo, M. \& Fernández, C. (2014). Engaged youth in Internet: The role of Social Networks in Social Active Participation. Comunicar, 22(43), 35-42. doi: http://dx.doi.org/10.3916/C43-2014-03

Gómez, R. \& Camacho, K. (2013). Users of ICT at Public. Access centers: Age, education, gender and income differences in users. In S. Chhabra (Coord.) (2013), ICT influences on Human Development, Interaction and Collaboration. (p.1-22). USA: IGI Global.

Gunjan, N. (2015). Professional Development Through Virtual Education and Training. International Journal of Innovation and Research in Educational Sciences, 2(5), 394-397.

Green, C. \& Bavelier, D. (2003). Action video game modifies visual selective attention. Nature, (423), 534-537. doi:10.1038/ nature01647 
Haan, J. (2011). Teaching and learning English through digital game projects. Digital Culture \& Education, 3(1), 46-55.

Hine, C. (2004). Virtual Etnography. London: Sage.

INE (2007). Encuesta sobre Equipamiento y Uso de Tecnologías de la Información y Comunicación en los hogares 2007. Disponible en: http://www.ine.es/jaxi/ tabla.do?path=/t25/p450/a2007/10/ \&file $=04019 . p x \&$ type $=$ pcaxis \&L $=0$

INE (2015). European Conference on Quality in Official Stadistics. Disponible en: h t t p s : / / w w w. g o o g l e.e s / we b h p ? s o u r c e i d = c hrom e instant \&ion $=1 \&$ espv $=2 \&$ ie $=U T F$ 8\#q=ine\%202015

Lalueza, L., Bria, M., Crespo, I., Sánchez, S. \& Luque, M. (2004). Education as creation of microcultures. From the local community to the virtual community. Interactive Educational Multimedia, (9), 1-20.

Lévy, P. (2007). Cyberculture. The culture of the e-society. Barcelona: Ánthropos.

López, E., Llorent, V.J. \& Fernández, E. (2013). Experiencia universitaria sobre las funciones del educador/a social con tecnologías 2.0. Edutec. Revista Electrónica de Tecnología Educativa, (43), 1-17.

Lorente, S., Bernete, F. \& Becerril, D. (2004). Young people, family relationship and Information and Communication Technologies. Madrid: Lerko Print.

Manzano, B. (2012). ICT School 2.0: Elementary student learning in educational social and family contexts. Granada: University of Granada.

Manzano, B. (2015a). The development of the digital competence in the Spanish basic educational law. Opción, (1), 828-853.

Manzano, B. (2015b). Gamification of teaching-learning processes in digital classrooms: an experience in UK primary schools, In Martínez \& Alonso (Coords.). Videojuegos: diseño y sociología (pp.239311). Madrid: ESNE.

Marcelino, M. (2015). Spanish youth and teenagers migrating through social networks. From Tuenti to Facebook and from Facebook to Instagram. The second migration. Icono14, 13(2), 48-72. doi: ri14.v13i2.821

Martínez, S. \& Raya, P. (2012). The microblogging in the teaching-learning process. An academic experience with Twitter. Historia y Comunicación Social, 18, 139-149. doi: http://dx.doi.org/10.5209/ rev_HICS.2013.v18.44232

Maurí, T. \& Onrubia, J. (2008). El profesor en entornos virtuales: Condiciones, perfil y competencias. In C. Coll \& C. Monereo (2008). La Psicología de la educación virtual (pp.132-152). Madrid. Morata.

Monereo, C., Tirado, F.J., Vayreda, A., Fuentes, M., Badia, A., Doménech, M., Escofet, A. \& Rodriguez, J.L. (2005). Internet y competencias básicas. Aprender a colaborar, a comunicarse, a participar, a aprender. Barcelona: Graó.

Morimoto, S.A. \& Friedland, L.A. (2011). The Lifeworld of Youth in the Information Society. Youth Society, 43(2), 549-567. doi: 10.1177/0044118X10383655

Observatorio nacional de las telecomunicaciones y de la SI (ONTSI) (2014). Perfil socio demográfico de los internautas. Análisis de los datos INE 2013. Madrid: ONTSI.

Pérez, A. (2011). Comunicación digital en la sociedad del siglo XXI. En Martínez, F. y Solano, I. (2011). Comunicación y relaciones sociales de los jóvenes en la red (pp. 83-96). Alcoy: Marfil.

Piscitelli, A. (2006). Nativos e inmigrantes digitales. ¿Brecha generacional, brecha 
cognitiva, o las dos juntas y más aún?. Revista Mexicana de Investigación Educativa, 11(28), 179-185.

Pozo, J. I. \& Monereo, C. (Coord.) (1999). El aprendizaje estratégico: Enseñar a aprender desde el currículo. Madrid: Aula XXI Santillana.

Rodríguez, E. (2002). Jóvenes y Videojuegos: Espacio, significación y conflictos. Madrid: Ministerio de Trabajo y Asuntos Sociales (INJUVE).

Ruiz, M. \& De Juanas, A. (2013). Social Networks, Identity and Adolescent: New educational challenges for the family. Estudios sobre educación, 25, 95-113. Retrieved from: http://www.unav.edu/web/ e s t u d i o s - s o b r e ed u c a c i o n / articulo?idArticulo=3529501

Sampedro, B. \& Marín V. (2015). Knowledge of the future social educators about 2.0 tools. Pixelbit, (47), 41-58. doi: http://dx.doi.org/10.12795/pixelbit.2015.i47.03

Sevillano, M.L. (2010). Sociedad de la información-sociedad del conocimiento: relaciones y convergencia. En M.L. Sevillano (Coord.). Nuevas tecnologías en educación social (pp.1-28). Madrid: Mc Graw Hill.

Solano, I.M., González, V, \& López, P. (2013). Teenagers and communication: ICT as a resource for social interaction in secondary school. Pixel Bit. Revista de Medios y Comunicación, 42, 23-35.

Sureda, J., Comas, R. \& Morey, M. (2010). Internet Access by minors at home: Usage norms by parents. Comunicar, 17(34). doi: 10.3916/C34-2010-03-13

The Cocktail Analysis (2011). $3^{a}$ Oleada del Observatorio de Redes Sociales. Disponible en: http://tcanalysis.com/blog/ posts/publicamos-la-3\%C2\%AA-ola-delobservatorio-de-redes-sociales
Trick, L. M., Jaspers, F. \& Sethi, L. M. (2005). Multiple-object tracking in children: The Catch the Spies task. Cognitive Development, 20(3), 373-387. doi:10.1016/ j.cogdev.2005.05.009.

Velasco, C., López, J. \& Noriega, C. (2013). Las Nuevas Tecnologías de la Información y la Comunicación en la familia. In M. Solano y M. Viñarás (Coords.) (2013). Las nuevas tecnologías en la familia y la educación; retos y riesgos de una realidad inevitable (pp.75-94). Madrid: CEU.

Vygotsky, L. (1979). Mind and Society: The development of Higher Psychological processes. Harvard University: Press.

Werstch, J. (1993). Voices of the Mind: A sociocultural approach to Mediated Action. Harvard University: Press.

Fecha de recepción: 24-01-2016

Fecha de evaluación: 29-02-2016

Fecha de aceptación: 24-03-2016 e-ISSN: 2171-7966. doi: http://dx.doi.org/10.12795/pixelbit.2016.i49.013 